\title{
Birleşik Krallık’taki Okullarda Ders Kitabı Kullanımı: Mevcut Durum, Çalışmalar, Gelecek Planları
}

\author{
Textbook Usage at Schools in the UK: Current Status, Studies, Future Plans
}

\author{
Doç. Dr. Nihal ÇALIŞKAN(iD)', Doktora Öğrencisi Mehmet TOYRAN(iD2
}

\begin{abstract}
$\ddot{O} z$
$\mathrm{Bu}$ çalışma, Birleşik Krallık eğitim sisteminde ders kitabı kullanımı konusuna 1 şık tutmayı amaçlamaktadır. Dünyanın birçok ülkesinde ders kitapları başlıca eğitim materyali olmasına rağmen, Birleşik Krallık eğitim sisteminde geçtiğimiz yüzyılın son yarısında ders kitabı kullanımı ortadan kalkmıştır. Bunda farklılaştırılmış öğretim ve öğrenmeyi öğretme yaklaşımları etkili olmuştur. Ancak, ders kitabı kullanımının başat olduğu Uzak Doğu ülkelerinin PISA gibi uluslararası sınavlarda elde ettiği başarılar, İngiliz eğitim otoritelerini Birleşik Krallık’taki ders kitabı karşıtllğı kültürünü sorgulamaya yöneltmiştir. Eğitim Bakanlığı, nitelikli ders kitaplarını kullanıma sunarak ders kitabı karşıtlığını zayıflatmak üzere çeşitli adımlar atmıştır. Şimdiye kadar matematik ders kitaplarında oldukça önemli bir mesafe kat edilebilmiştir. Eğitim otoriteleri, Birleşik Krallık'taki okullarda ders kitabı kullanımını yaygınlaştırma yolunda çaba sarf etmekle birlikte, eğitimin bireysel olması gerektiği yönündeki köklü düşünce, bütün tarafları ikna etmenin uzun zaman alacağını göstermektedir.
\end{abstract}

Anahtar Kelimeler: Birleşik Krallık, eğitim sistemi, ders kitabı, materyal

Makale Türü: Araştırma

\begin{abstract}
This study aims to shed a light on textbook use in the UK education system. Although being the primary course material in many countries through the World, textbooks have fallen out of use in the UK during the last quarter of the century. The philosophy of differentiated teaching and "teach how to learn" have played a great part in shaping this change. However, the success of Far East countries, where the textbook use is dominant, in international exams such as PISA urged British educational authorities to question the anti-textbook culture in the UK. Ministry of Education has taken a step to counteract against this antitextbook culture by introducing high quality textbooks to the UK schools. So far, considerable progress has been made in maths textbooks. The authorities aim to widen the use of textbooks in the UK schools, but it seems this will take a long time to persuade all parties in the educational system due to the deepseated view that education must be individualized.
\end{abstract}

Keywords: United Kingdom, education system, textbook, material

Paper Type: Research

\footnotetext{
${ }^{1}$ Yıldırım Beyazıt Üniversitesi, İnsan ve Toplum Bilimleri Fakültesi, caliskanihal@hotmail.com.

${ }^{2}$ Atatürk Üniversitesi, Eğitim Bilimleri Enstitüsü, toyran1@gmail.com.
}

Atıf için (to cite): Çalışkan, N. ve Toyran, M. (2020). Birleşik Krallık'taki okullarda ders kitabi kullanımı: mevcut durum, çalışmalar, gelecek planları. Afyon Kocatepe Üniversitesi Sosyal Bilimler Dergisi, 22(3), 693-705. 


\section{Giriş}

"Nasıl bireyler yetiştirmeliyiz?" sorusuna cevap aramak üzere inşa edilen eğitim sistemleri, ülkelerin eğitime bakışının genel bir özetidir. Bir idealin ürünü olarak ortaya çıkan bu sistemler, ihtiyaçlar nispetinde değişir ve gelişir. Eğitimde başarılı olmak, öncelikle sağlıklı bir sistemin kurulabilmesi ile mümkündür. Çağa uygun bir biçimde kendini yenilemek durumunda olan bu sistemlerin başarısını, basılan ve okunan kitap sayısı, uluslararası ölçme ve değerlendirme sınavlarının sonuçları, yükseköğretim kurumlarının uluslararası sıralamalardaki yeri, sanayi ve üretime ilişkin veriler başta olmak üzere pek çok değişken aracılığıyla değerlendirmek mümkündür.

Eğitim sistemlerinin hedefe yönelik söylemleri, sistemin uygulanışına ilişkin esas ve yöntemlerin çerçevesini çizen öğretim programları ile ortaya konur. Eğitim, bütün dünyada ideal olanın izini sürdüğünden öğretim programları büyük ölçüde benzer amaç ve hedefler barındırır. Türkiye'deki öğretim programlarının genel amacı tüm programlarda aşağıdaki şekilde ifade edilir:“...birey olmanın aynı zamanda çok daha geniş bir "dünya ailesi”ne ait olmak olduğunun bilincine varacak, yaşadığı topluma ve ülkesine, toprağına samimi bir hisle bağlanacak, bilim ve teknolojiyi etkin şekilde kullanarak gerekli teknik bilgi, birikim, beceri ve yeterliliklere sahip kuşaklar yetiştirmek hedeflenmiştir." (Coşkun, 2017, s. 10). İngiltere'de de son olarak 2014 yılında güncellenen Ulusal Müfredat'ta (National Curriculum) “...Çocukların canlı bir kişiliğe sahip olmalarını sağlamada yardımcı olmak; kendisinden farklı değerleri olan başka ırk, din ve yaşam biçimlerine sahip insanlara saygı duymak; çocukların ulusların özgürlüğü ve yaşadıkları dünyayı anlamalarına yardımcı olmak; okuma-yazma becerisinin yanı sıra konuşmada etkili bir dil kullanmalarına yardım etmek; öğrencilere bilimsel ve matematiksel bir temel sağlamak..."3 ifadeleri yer almaktadır. Öğretim programlarında idealize edilen bu amaç ve hedefleri eyleme dökmek, eğitime yön veren kurumların organizasyon kabiliyetiyle mümkün olabilmektedir.

$\mathrm{Bu}$ organizasyon sağlam bir şekilde yapılandırılabilirse yakalanan kalite, eğitimle ilgili diğer paydaşlara da sirayet edecektir. Bu çalışmanın konusunu oluşturan ders kitabı kullanımı hususu da sistemin işlerlik kazanmasında önemli etkenlerden biri durumundadır.

\section{Ders Kitaplarının Eğitimdeki Yeri}

Dijital Çağ denilen günümüz dünyasında basılı yayınların piyasadan yavaş yavaş kalkacağı konuşulsa da ders kitapları, birçok ülkede eğitimin önemli bir unsuru olmaya devam etmektedir. Bunun en önemli nedeni, Pingel'in (2003, s. 12) de belirtmiş olduğu gibi ders kitabı metinlerinin ulusal kültüre ilişkin temel fikirleri yansıtmalarından kaynaklanmaktadır. Özellikle ana dili dersi ile sosyal bilimlerle ilgili dersler, öğrencilerin fikir dünyalarına etki etmeye; onlara millî bir bakış açısı ve arzu edilen manevi değerleri kazandırmaya uygun derslerdir. Bu nedenle Gürses ve Pazarcı'nın ifadesiyle "eğitimin ulusal ölçekte yapılmadı̆̆ı ülkelerde bile okul kitaplarının içeriği, devletin ilgilenmekten vazgeçemeyeceği kadar önemli olmuştur." (2010 s. $1)$.

Ders kitapları, bir toplumun geleceğine ilişkin tasarımları yeni kuşaklara aktarmak için de önemli bir araçtır. Amerika'da gerçekleşen siyasal toplumlaşma sürecinde eğitim verme yetkisine sahip çoğu eyalette 13 ve 14 yaşındaki öğrenciler için özel bir Yurttaşl1k Bilgisi dersi zorunlu tutulmuştur (Kaplan, 1999, s. 124). Japonya'da da mevcut siyasal düzeni koruma ve sürdürmeye yönelik "sosyalizasyon simgeleri" aritmetik ve müzik gibi sosyal bağlamdan uzak olduğu düşünülebilecek derslerde bile kullanılmıştır (Alkan, 1979, s. 68). Elbette ders kitaplarına biçilen rol, ülkeden ülkeye değişiklik göstermektedir. Uyan eğitimde gösterdiği

\footnotetext{
${ }^{3}$ National Curriculum 2014: “...Helping children to have a lively personality; to respect other people of different race, religion and lifestyle with different values; to help children understand the freedom of nations and the world they live in; assisting them to use an effective language in speaking as well as reading-writing skills; To provide students with a scientific and mathematical foundation..."
} 
başarı ile adını duyuran Finlandiya'daki ders kitabı kullanımı ile ilgili gözlemlerini şöyle aktarmaktadır: "Bizde müfredat ve ders kitapları eğitimin baş aktörleri olarak biliniyor. Eğitim kalitesindeki zayıflık genelde bu ikisinin suçu olarak görülüyor. Ama Finlandiya'da çok basit bir müfredat var ve pek değişmiyor. Öğretmenler okutulacak kitapları kendileri seçiyorlar ama yine de ortalıkta pek ders kitab1 gözükmüyor.” (2015, s. 6).

Ders kitabı kullanımı veya ders kitaplarının eğitim sistemlerindeki yeri ile ilgili genel bir değerlendirmede, Türkiye'nin ders kitaplarına önem veren ve ders kitaplarını eğitimin temel unsuru olarak kabul eden ülkeler arasında bulunduğunu söylemek hatalı olmayacaktır. Bu anlayışın temelinde, başka gerekçelerin yanında, birtakım değerleri kontrol altında tutma ve bu değerleri kitaplar vasıtasıyla yeni nesillere aktarma motivasyonu da vardır. Millî ve manevî değerlerin ders kitapları vasıtasıyla topluma yerleştirilme çabası cumhuriyetin ilk yıllarından itibaren Türkiye'de siyasî iradenin müdahale ettiği hususlardan biri olmuştur. 1980 döneminde ve sonrasında okullardaki Millî Güvenlik derslerine askerlerin giriyor olması bunun en somut örneğidir. Son olarak 2018 yılında güncellenen Türkçe Öğretim Programı'nda ilk defa “değerler eğitimi” kavramının yer almış olması, Türkçe ders kitaplarına bu kavramla ilgili içerik bulundurulması zorunluluğu getirilmiş olması da aynı yaklaşımın bir ürünüdür. Öte yandan genç nüfusun yoğun olduğu bir ülke olarak ders kitaplarının pratik bir öğretim materyali olması da tercihleri belirlemede etkili olmaktadır. Türkçe ders kitaplarıyla ilgili çalışmasında Göçer (2007, s. 197-198), temalara uygun metinler içerme, öğrenci seviyesine uygunluk, öğrenci alıştırma kitabıyla uyumluluk, ölçme-değerlendirme konusunda zenginlik gibi ölçütler doğrultusunda yüksek bir standardı sağlayabilen ders kitaplarının kolay ulaşılabilirlik ve bütün öğrenciler tarafından yaygın bir şekilde kullanılabilirlik imkânıyla öğretimi destekleyecek bir araç olduğunu vurgulamaktadır.

Eğitim genel itibarıyla dinamik bir süreçtir. Eğitimle ilgili birçok hususun yeniden gözden geçirildiği günümüzde, derslerdeki kitap ve kaynak kullanımının sorgulanması modern eğitim anlayışının bir gereğidir. Özellikle teknoloji ile beraber öğrenme yöntem ve alışkanlıklarının değişmesi göz önünde bulundurulduğunda ders kitaplarının sistemdeki işlevi yeniden ele alınıp değerlendirilmelidir. Köklü bir eğitim geleneğine sahip olan İngiltere'deki okullarda kurum kültürü, disiplin, geleneksel eğitim yöntemleri gibi eğitimin özüne dair birçok husus hâlâ önemini korurken ders kitaplarının hem devlet okullarında hem de özel okullarda kullanımının yok denecek kadar az olması dikkat çekicidir. Bu durum kanaatimizce, Türkiye ve İngiltere arasında eğitim pratikleri açısından kolayca gözlemlenebilir durumdaki en büyük farklılık durumundadır.

Eğitim araştırmalarında sıkça referans gösterilen PISA sonuçlarına baktığımızda OECD ülkeleri ortalamasının 493 olduğu 2015 yılında, okuma testinde İngiltere'nin ortalama puanı 498, Türkiye'nin ise 428'dir. İlk üç sıradaki Singapur, Hong Kong ve Kanada'nın puanları sırasıyla 535, 527, 527; son üç sıradaki Cezayir, Kosova ve Lübnan'in 350, 347, 347'dir. En yüksek puanın 556 (Singapur) olduğu fen alanında İngiltere'nin puanı 509; Matematikte ise Singapur 564 iken İngiltere'de 492'dir. Türkiye'de ise sırasıyla bu puanlar 425 ve 420'dir.

PISA sınavlarından elde edilen verilerin ülkelerin eğitim sistemlerinin değerlendirilmesi ve eğitim politikalarının belirlenmesindeki rolüyle ilgili tartışmalar devam etmekle birlikte (Araujo vd. 2017, Fernandez-Cano 2016, Goldstein 2017, Sjøberg 2015, Sjøberg 2018) gerek Türkiye'de gerekse İngiltere'de dikkatlerin yüksek puan alan ülkelere çevrildiği ve bu ülkelerdeki eğitim pratiklerinden nelerin transfer edilebileceği konusunda bir arayış olduğu gözlemlenmektedir. Bu noktada ders kitabı kullanımı ilginç bir araştırma konusu olarak ortaya çıkmaktadır. Zira 2015 yılı PISA sınavının tüm alanlarda ilk sırada yer alan ülkesi Singapur'da ders kitabı yaygın biçimde kullanılırken İngiltere'de bu oran oldukça düşüktür. Öte yandan PISA sınavında her üç alanda da OECD ortalamasının oldukça altında olan Türkiye'de ders kitapları temel öğretim materyali durumundadır. Son yıllarda, İngiltere'de gözler PISA sınavlarında dikkat çekici bir başarı yakalayan Uzak Doğu ülkelerine çevrilmiş olup 2010 
y1lında okullardan sorumlu eğitim bakanı olan Nick Gibb'in gayretleriyle, ders kitabı kullanımın yaygınlaştırılması konusunda çalışmalar artırılmıştır.

Ders kitaplarının Talim ve Terbiye Kurulu Başkanlığınca bir yönetmelik ve kriterler (Millî Eğitim Bakanlığı Ders Kitapları Ve Eğitim Araçları Yönetmeliği-2016) dâhilinde incelenerek çeşitli onay süreçlerinden geçmek kaydıyla belirlendiği Türkiye'de ise ders kitaplarının kalitesi, eğitimin çözüm bekleyen önemli sorunlarından biri olmaya devam edegelmiştir (Özgen, 1993; Demirkaya ve Tomal, 2002; Altun vd. 2004; Işsksalan, 2004; Çalışkan, 2006; Ülper ve Yalınkılıç, 2010; Çakır, 2013; Gülersoy, 2013).

\section{Yöntem}

Çalışma kapsamında veriler iki yolla elde edilmiştir. Bunlardan ilki nitel araştırmalarda sıkça kullanılan gözlem ve onu takip eden görüşme yöntemi, ikincisi ise doküman analizidir (Yıldırım ve Şimşek, 2016). Makale yazarları üç yıldır İngiltere'de bulunmakta olup her ikisinin de ilk ve orta okula giden çocukları vardır. Ayrıca yazarlardan biri İngiliz okullarında Türkçe ve Türk Kültürü Öğretmeni olarak görev yapmaktadır. Üç yıllık süre zarfında çocukların okul hayatına ilişkin yapılandırılmamış gözlemlerden ders kitabı ve materyal kullanımı konusunda elde edilen veriler sistematik bir şekilde listelenmiş, daha sonra çocuklar ve öğretmenlerle görüşülerek listelenen hususların doğru değerlendirilip değerlendirilmediği kontrol edilmiştir. Çalışmada kullanılan ikinci yöntem doküman analizidir. Bunun için İngiltere'de ders kitabı kullanımı konusundaki tartışmaların ye aldığı hükümet siteleri, ders kitabı kullanımı konusunda hükümete sunulan 2014 tarihli rapor, konuyla ilgili olarak öğretmenler ile eğitim sendikalarının görüşlerine haberleştiren gazete yazıları ile veli perspektifini yansıtmak üzere blog ortamında yapılan tartışmalar incelenerek analiz edilmiştir.

\section{İngiliz Eğitim Sistemi ve İngiltere'de Ders Kitabı Kullanımı}

İngiltere'de eğitimin sorumluluğu, merkezî hükümet eliyle Eğitim Bakanlığındadır (Department for Education). Fakat söz konusu sorumluluk, yerinden yönetimi kolaylaştırmak amaciyla yerel yöneticilere (Local Education Authorities, LEAs), gönüllü kuruluşlara, eğitim kuruluşlarının yönetim organlarına dağıtılmıştır. "İngiltere'de 1986 yılında düzenlenen "Okulların Yönetimi” çalışmasıyla, eğitim yönetimi ile ilgili yetkilerin büyük çoğunluğu okullara devredilmiştir" (Çınkır, 2010: 60). İngiltere'de eğitimin temel amaçları ve yol haritasını belirlemede en önemli referanslardan biri de hiç şüphesiz Ulusal Program (National Curriculum)'dır. Ulusal Program, en son 2014 y1lında güncellenmiştir.

Türk eğitim sistemi ile kıyaslandığında İngiliz eğitim sistemi yerelleşme özelliği ile ön plana çıkmaktadır. Eğitimin yerelleşmesi ulusal bir öğretim programı uygulanırken okullara da bireysel olarak kendi programlarını yapma, ders materyallerini belirleme konusunda otonomi verilmesi olarak karşımıza çıkar (Bakioğlu, 2018, s. 290). Birleşik Krallık'a bağlı diğer ülkelerde (Galler, İskoçya, Kuzey İrlanda) ders kitapları nispeten daha çok kullanılırken İngiltere'de öğrencilere ders kitabı dağıtılmadığı gibi herhangi bir kitap tavsiyesinde de bulunulmaz. Hangi sınıf seviyesinde, hangi konuların nasıl öğretileceği Ulusal Program'ın ilgili kısmında açık bir şekilde izah edilmektedir. Söz gelimi İngilizce okuma-yazma öğretiminde son derece önemli bir başlık olan yazım (spelling) konusunda hangi sınıf düzeyinde hangi kelimeler üzerinde durulacağı listelenmiştir. Bununla birlikte programdaki konuların hangi sıraya göre nasıl işleneceği okullara, zümre ve ders öğretmenlerine bırakılmıştır.

Hem gözlem yaptığımız İngiliz okullarında hem de örgün eğitim içerisinde görev yapan öğretmenlerden aldığımız bilgiler doğrultusunda İngiltere'deki ders kitabı kullanımı konusunda aşağıda sıralanan hususlar öne çıkmaktadır:

- İngiltere'deki ilk ve orta dereceli (primary-secondary) okullarda "textbook" adı verilen ders kitapları kullanımıyla ilgili herhangi bir zorunluluk yoktur. Eğitime yön veren kurumların derste kullanılacak kitaplarla ilgili herhangi bir tavsiye veya tasarrufu söz konusu değildir. Ancak, okul ders için seçilen materyali ücretsiz olarak temin etmekle yükümlüdür. 
- Ders kitabı kullanımının yaygın bir pratik olmaması, öğretmenlerin materyal geliştirme sürecinde aktif biçimde rol almasını da beraberinde getirmektedir. $\mathrm{Bu}$ noktada öğretmenler kendi ders materyallerini geliştirme ya da eğitim sitelerinden seçip aynen veya düzenlemek suretiyle kullanma özgürlüğüne sahiptir.

- Öğretmenlerin derslerde hangi kaynağı (materyal, web sitesi vb.) kullanacağı zümre öğretmenler kurulunun kararı ve okul idaresinin onayı ile olabilmektedir. Zümre öğretmenleri bulunmayan küçük okullarda ise öğretmenler, ilgili müdür yardımcısı ya da okul müdürüyle birlikte kararlar alabilmektedir.

- Öğretmenlerin derslerde kullandıkları çalışma kâğıtları, her ders için okul tarafından temin edilen defterlere ilkokulda öğretmen ya da yardımcı öğretmen, ortaokulda ise öğrencinin kendisi tarafından yapıştırılmaktadır. Bu defterlere de kitap (book) adı verilmekte, böylelikle öğrencilerin dönem ya da yılsonunda dersle ilgili bir arşive sahip olmaları sağlanmaya çalışılmaktadır. Çalışma kâğıtları genellikle renkli olarak basılmaktadır.

- İngiltere'deki eğitim sisteminde ders kitaplarının kullanılmaması eğitimle ilgili kaynak sağlayan sitelerin gelişmesine ortam hazırlamıştır. Öğrencilerin ilgisini çekebilecek canlılıkta içerik barındıran bu eğitim sitelerinden bazıları bütün derslerle ilgili kaynak imkânı sunarken bazılarında ise sadece belli derslerle ilgili materyaller bulunmaktadır. İngiltere eğitim sistemi içerisinde İngilizce ve matematik dersleri temel olarak kabul edildiği için bu iki derse ilişkin kaynak barındıran sitelerin sayısı ve bu derslerle ilgili materyaller hâliyle daha fazladır. ${ }^{4}$

- Eğitim için materyal imkânı sunan siteler ücretli ve ücretsiz olarak ikiye ayrılmaktadır. Daha nitelikli içerik barındıran siteler genellikle ücret karşılığı hizmet verebilmektedir. Kimi zaman okul olarak kimi zaman da öğretmenler bireysel olarak bu sitelere üye olabilmektedir. Ücretli siteler öğretmen ve velilerin talepleri doğrultusunda siteye yeni materyaller koyabilmektedir.

- İngiltere'de sitelerin eğitime desteği sadece materyal boyutunda değildir. Öğrencilerin ödev yapmaları için de platformlar bulunmaktadır. Okullar böyle bir platform kullanacaklarsa kurumsal üyelik yolunu tercih etmekte, öğrenciden herhangi bir ücret talep edilmemektedir. $\mathrm{Bu}$ siteler üzerinden yapılan ödevleri öğretmenler ve veliler kontrol edebilmektedir. İnternet erişimi bulunmadığını beyan eden öğrencilere, bu ödevler basılı olarak dağıtılmaktadır.

- İngiltere'de köklü bir geçmişe sahip özel eğitim kurumları, dünyanın dört bir yanından gelen öğrencilere de ev sahipliği yapmaktadır. Bu tür eğitim kurumları kendi hazırladıkları ders kitaplarına ve kendi materyallerini içeren eğitim sitelerine sahiptirler.

- Öğretmenlerin mesailerinin ve çoğu zaman da mesai dışı zamanlarının önemli bir bölümünü materyal hazırlamaya ayırmaları son derece yorucu olmakla birlikte sistemin işleyişi bu pratiğin devamlılığını garanti altına almaktadır. Çünkü öğretmenler sözleşmeli olarak görev yapmakta ve bulundukları kurumda kalıcı olmak veya daha nitelikli bir okulda görev alabilmek için -tabiri caizse- başarıya mahkûm edilmektedir. Bu durum sistemin devreye soktuğu bir otokontrol mekanizması olarak dikkat çekmektedir.

\section{İngiltere'de Ders Kitabı Kullanımı Konusunda Güncel Tartışmalar}

Türkiye'de ders kitabı kullanımının nicel ve nitel yönlerini ele alan gerek kitap gerekse makale, bildiri, rapor boyutunda pek çok çalışma yapılmış olmasına, konuyla ilgili bir dizi çalıştay düzenlenmiş olmasına rağmen İngiliz eğitim bilimleri literatüründe bu doğrultuda bir birikim olduğunu söylemek mümkün değildir. Tabii bu, "var olmayan bir durum üzerine" zaten görüş bildirilemeyeceği gibi bir argümanla doğal karşılanabilir. Ancak ders kitabı kullanımının farklı ülkeler bağlamında değerlendirerek İngiliz okullarında da ders kitabı kullanımının

\footnotetext{
4 Türkiye'de de çok sayıda eğitim sitesi vardır. Ancak bu sitelerde yer alan materyaller öğretmenlerin hazırlayıp kendi inisiyatifleriyle siteye yükledikleri, herhangi bir denetimden geçmeyen, bütüncül olma gayesiyle hazırlanmamış malzemeler olup geribildirimler aracılığıyla düzeltilerek yeniden yayınlanmaları da söz konusu değildir.
} 
yaygınlaştırılmasını bir seçenek olarak masaya yatıran çalışmalar da yok denecek kadar azdır. İngiliz yayıncılık piyasası da ders kitabı üretimi konusunda, bütün enerji ve birikimini İngilizcenin ikinci/yabancı dil olarak öğretimi alanına sarf etmiş gibi görünmektedir. Bu yüzden yukarıda sözünü ettiğimiz üzere okullardan sorumlu eğitim bakanı Nick Gibb'in öncülük ettiği ders kitaplarını yaygınlaştırma çabaları önem kazanmaktadır.

İngiltere eğitim sisteminde ders kitabı kullanımı 1970’lerden itibaren giderek azalmış, 2000'li yıllarda ise neredeyse tedavülden kalkma noktasına gelmiştir. Ancak 2014 yılında eğitim uzmanı Tim Oates tarafından hazırlanan rapor gerek resmî makamlar nezdinde, gerekse kamuoyunda ilgi görmüş ve o tarihten bugüne ders kitaplarının yeniden temel eğitim materyali olarak kullanılmasını özendirmeye yönelik çalışmalar ağırlık kazanmıştır. Oates (2014), Ders Kitapları Neden Önemlidir? (Why Textbooks Count?) başl1klı raporunda, ders kitab1 kullanımının PISA sınavlarında tutarlı bir başarı çizgisi yakalamış Singapur'da \%70, Finlandiya'da \%95 iken İngiltere'de ancak \%10'larda olduğu tespitini yaparak 1970'lerden itibaren ders kitabı kullanımına karşı ideolojik bir düşmanlık başlatıldığını; diğer ülkelerde teorik açıdan sağlam, iyi tasarlanmış, dikkatlice uygulanan ders kitaplarıyla ilgili gerçeğin farkına varamadıklarını, çalışma kâğıtlarıyla öğretmenin yükü artırılırken ders içeriğinin tutarlı ve ulusal standartlara uygun biçimde yürütülmesi zarar gördüğünü söylemektedir. Oates'in bu rapordaki görüş ve tespitlerini maddeler hâlinde şöyle özetlemek mümkündür:

- Ulusal yeterliliklerin hem biçim hem de içerik açısından sık sık değiştirilmesi nitelikli ders kitaplarının yazımını güçleştirmekte; Şangay ve Singapur'da görülen değerlendirme (evaluation) ve rafine etme (refinement) süreçlerine engel teşkil etmektedir. (s.4)

- Oysa nitelikli ders kitapları; sağlam öğrenme teorileriyle desteklenir, anahtar kavram ve bilgilere odaklanarak içeriği net bir şekilde resmeder, konuyla ilgili tutarlı bir devamlılık sağlar, öğrencinin konu üzerinde derinlemesine düşünmesini destekler, kavram ve ilkelerin çeşitli şekillerde uygulamasını gösterir, metinlerin hem yapısal hem de yüzeysel özellikler bakımından temeldeki öğrenme teorisiyle uyumluluğunu kontrol altına alır. (s.4, 5)

- Dijitalleşmeyle birlikte çevrimiçi materyallere yönelim, ders kitaplarıyla elde edilen birikimin kaybolmasına yol açmamalıdır. (s.5)

- Ortak kriterler doğrultusunda hazırlanan ders kitaplarının gereğinden fazla kuralcı olduğu söylenebilir ancak sağlam ve güvenilir değerlendirme süreçlerinde başlangıçta sınırlayıcı gibi görülen kriterlerin temel bileşenler söz konusu olduğunda gevşediği görülmektedir. Üstelik bu tür süreçlerden geçerek hazırlanan ders kitaplarının sınıf bağlamında kullanımında da esneklikler görülebilmektedir. (s.5)

- Başarılı öğretmenlerin ders kitabı kullanma konusunda daha istekli olduğunu gösteren araştırmalar vardır (Reynolds ve Farrell, 1996). Çünkü ders kitapları, öğretim programının amaçlarıyla tutarlılık sergilemekte, iyi tasarlanmış biçimlendirici ölçme-değerlendirme malzemesi sunmakta ve öğretmene zamanını materyal geliştirmek yerine öğrencilerin gelişimine odaklanmak için kullanma firsatı vermektedir. (s.5, 6)

Oates'in bu raporunda öne sürülen argümanlar doğrultusunda Bakan Nick Gibb, 2014 yılında anti-ders kitabı görüşüne karşı velilere seslenmiş ve okullarda hâlihazırda kullanılan çalışma kâğıtlarını hazırlamanın zaman alıcı bir iş olduğu ve bunları sistemli biçimde bir arada tutmanın çoğu zaman mümkün olmadığı; buna karşılık ders kitaplarının öğrenciye daha yapılandırılmış bir öğretim sunacağı, okulların tasarruf etmesini sağlayacağı, ebeveynin okul dışında çocuğun derslerine yardımcı olmasını kolaylaştıracağı, öğrenciyi sınav müfredatının sınırlılıklarından kurtaracağı gerekçeleriyle destek istemiştir. Bakan, bu konuşmasında mevcut ders kitaplarının daha çok sınav odaklı olduğuna da dikkat çekmiştir (The Telegraph, 20.11.2014). ${ }^{5}$ Gibb'in bu çağnısı ilerleyen günlerde de medya organlarında yankılanmaya

\footnotetext{
${ }^{5}$ İngiltere'de lise bitirme (GCSE) ve üniversiteye giriş (GCSE-A Level) şeklinde nitelendirebileceğimiz iki temel sınav yapılmaktadır. Bunlardan ilkinde öğrenci, lise diploması almak için zorunlu ve seçmeli derslerden oluşan bir dizi sınava
} 
devam etmiş; BBC ve The Telegraph başta olmak üzere, çeşitli yayın organlarında Oates'in raporu haberleştirilmiş; konuyla ilgili öğretmen görüşlerine yer verilmiştir. The Telegraph'ın "No textbooks? No wonder chidren aren't learning (Ders kitabı yok mu? Çocukların neden öğrenemediğine şaşırmamak lazım.) başlığıyla sunduğu haberde, İngiltere'nin önde gelen yatılı okullarından birinde görev yapmakta olan bir İngilizce öğretmeni, ders kitaplarının okul derslerini pratik bir şekilde desteklediğini belirtmekte; gramer kitabı olmadan yabancı dil dersi veya harita ve görseller olmadan tarih, coğrafya dersi olamayacağını ifade ederek ders kitaplarının bu malzemeyi kolayca sunma işlevini vurgulamaktadır. İnternet ortamındaki bilgilerin yoğun olmakla birlikte sistematik olmadığına işaret ederek öğrencinin tek başına ödev yaparken de ders kitaplarına başvurabileceğini, bunun yanı sıra ders kitabı üzerinde not alma ya da işaretleme yoluyla zorlanılan konuları belirginleştirme imkânı olduğunu belirten öğretmen, öğrencilerin kendilerinin de ders kitabına ihtiyaç duyduklarını söylediklerine dikkat çekmektedir. Yine bu ifadelerden öğrendiğimiz kadarıyla, fotokopi yoluyla çoğaltılıp dağıtılan materyaller, öğrenciye güven vermemekte; hatta bir ölçüde hayal kırıklığına sebep olmaktadır. Öğretmen sözlerini "(Ders kitapları) çoktandır görmediğimiz arkadaşlar gibidir. İçlerindeki resimler -bunu söylediğime üzgünüm ama çoğu kez yüzleri sakal bıyık ve grafitilerle değiştirilmiştir- bana bulanık ve uzak bir geçmişteki okul günlerimin mutlu anılarını getiriyor. Ne diye yeni nesiller bu hazinelerden mahrum bırakılsın ki?" şeklinde bitirerek kitap ile insan arasında kurulan duygusal bağa da işaret etmektedir. Burada ders kitabı kullanımını destekleyen öğretmenin özel bir yatılı okulda görev yapması aslında üzerinde durulması gereken bir durumdur. İngiliz yasalarına göre, devlet okulları veliyi ders kitabı almaya zorlayamaz. Muhtemelen özel okullarda ders kitabı bütçesi okulun yıllık ücretinin yanında çok cüzi bir miktara karşılık geldiği ve velinin alım gücü problemi olmadığ 1 için ders kitapları kullanılabilmektedir. Oates, ders kitabı kullanımının öğrenci başına günlük 50 penny (yaklaşık 4 TL) gibi bir maliyeti olduğunu tahmin ederek fotokopi masrafının da aşağı yukarı aynı olduğunu ifade etmektedir (https://www.cambridgeassessment.org.uk/insights/why-do-studentsstill-need-textbooks/). Ancak İngiltere'de ders kitaplarının ücretsiz dağıtımı gibi bir seçenek üzerinde pek durulmadığı görülmektedir.

İngiltere'de okulun veliden ders kitabı almasını isteme hakk1 olmamas1, devletin de kitapları ücretsiz dağıtmaya yönelik bir politikasının bulunmaması nitelikli kitaplar üretebilecek durumdaki yayınevlerinin de piyasaya girmesini engellemektedir. Fakat bu şartlar gerçekleşmiş olsa bile, Özel Okullar Birliği Başkanı Lenon'ın da dikkat çektiği üzere, İngiliz eğitim sistemine yön veren dinamiklerden biri olan "farklılaştırılmış (differentiated) öğrenme", yani her öğrencinin kendi gelişim düzeyine göre bir gruba dâhil olmasını ve ilerledikçe grup değiştirmesini sağlayan mekanizma da bunun önünde ciddi bir engeldir (The Teleghraph, 15.07.2015). Gerçekten de görev yaptığımız veya veli olarak gözlemleme imkânı bulduğumuz kadarıyla özellikle matematik ve ana dili derslerinde çok keskin biçimde yapılandırılmış bir farklılaştırılmış öğrenme modeli uygulanmaktadır. Buna göre aynı sınıftaki öğrencilerden bir kısmı okuma-yazmanın "sesleri ayrıştırma, harfleri tanıma" aşamasındayken bir kısmı uzun hikâye kitapları okuyup kendi hikâyelerini yazabilecek durumdadır. Bu durum, aynı materyalin kullanımı önünde büyük bir engel teşkil etmektedir. Ancak Lenon aynı yazısında, dezavantaj biçiminde değerlendirilebilecek durumların yanında, ders kitaplarının "fiziksel kullanım kolaylığı sağlaması, dersi veya dersin bir bölümünü kaçıran veya anlamayan öğrenciler için hem kendi başına hem de veliyle birlikte çalışırken rehber niteliği taşıması, not alma becerilerini geliştirmesi ve hatırlamayı kolaylaştırması" gibi özelliklerinin gözden kaçırılmaması gerektiğini de ifade etmektedir.

İngiltere'de ders kitapları ile ilgili tartışmalarda bazen politik duruşlar da gündeme gelmektedir. Aslına bakılırsa Uzak Doğu ülkelerinin uluslararası sınavlarda elde ettiği başarılar,

girmektedir. Bu sınavlar merkezî olmayıp sınava giriş tarih ve sayılarında esneklik vardır. Öğrenci üniversite eğitimine devam etmek istiyorsa lise eğitimini müteakip 2 yıllık bir eğitim almakta, bu sürede de okumak istediği bölümün öngördüğü derslerden ikinci bir sınava daha girmektedir. GCSE-A Level denilen bu sinavlar ileri düzey bilgi ve beceri sinavlarıdır. 
her türlü yenilik ve gelişmenin Batı kökenli olduğu konusunda sarsılmaz bir kanaate sahip çevreleri şaşırtmıştır. Yukarıdaki yazısında Lenon, Barack Obama'nın da eğitim danışmanlığını yapmış Amerikalı bir eğitimcinin, yayın dünyasının dijitalleştiği gerekçesiyle İngiliz okullarına 5 y1l içinde ders kitaplarından tümüyle vazgeçme şeklindeki tavsiyesine "Eğitim sistemlerinin başarı ve başarısızlıkları hakkında bilgi sahibi olduğumuza göre, Amerikalı danışmanlar yerine

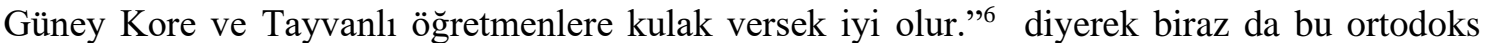
bakış açısına karşı pozisyon almıştır.

Lenon'un dile getirdiği farklılaştırılmış öğrenme modeli ve ders kitabı kullanımı ilişkisi, Eğitim Bakanı Nick Gibb'in Yayıncılar Birliği ve İngiliz Eğitim Sağlayıcıları Birliği (PABESA/The Publishers Association-British Educational Suppliers Association)'nin 2015 y1l Kasım ayındaki kongresinde özellikle vurguladığı hususlardan biridir. Bakan, kongrenin açılış konuşmasında anti-ders kitabı akımını besleyen kaynaklardan birinin İngiliz eğitim sisteminde konu alanına ilişkin içeriğin öğretim programının temeli olmaktan çıkarılması ve bunun neticesinde öğretmenlerin geleneksel olarak ders kitaplarına nüfuz etmiş sistematik bilgiden uzaklaşması; diğerinin ise öğretimin, her bireyin ilgi ve ihtiyaçlarına göre tasarlanması gerektiği inancı olduğunu ifade etmiştir. Bu değişkenlere bağlı olarak ortaya çıkan arz-talep dengesinin ders kitaplarının bütünüyle sistem dışına itilmesi sonucunu getirdiğini ifade eden Gibb, 2014 'ten beri yürütmekte oldukları çalışmaların en azından "ders kitabı arzı" noktasında belli bir yere geldiğini belirtmiştir. Bu süre zarfında Bakanlık, 35 matematik yuvasının” öncülüğünde ilkokul matematik öğretmenlerinin Singapur'dan adapte edilen 2 matematik kitabının pilot uygulamasını yaptırmıştır. Ulusal Birinci Sınıf Matematik Eğitimi Merkezi (National Centre for Excellence in Mathematics-NCETM), 1 yılı değerlendiren kısa bir rapor hazırlamış; raporda öğretmenler ve öğrencilerden alınan olumlu dönütlere yer verilmiştir. Bu girişim, eğitim yayıncılığı alanında uluslararası düzeyde tanınırlığı olan Collins Yayınlarını, Şangay matematik ders kitaplarını adapte ederek Busy Anths adıyla bir matematik serisi yayınlamaya teşvik etmiş̧tir. Yine Bakanın konuşmasından öğrendiğimiz üzere, Hodder ve Cambridge gibi önde gelen yayın evleri, lise bitirme ve üniversite giriş sınavlarına yönelik olarak hazırladıkları tekrar kitaplarının (revision guide) formatında değişikliğe gitmiş; daha önce bizdeki soru bankalarına benzeyen kitapları alan bilgisine yönelik içeriği zenginleştirerek bir tür konu anlatımlı soru bankasına dönüştürmüşlerdir. Bütün bu gelişmelerin yanı sıra Bakanlık, "yüksek kalitede okul kaynakları (high-quality school resources)" kavramlaştırmasıyla, yayınevlerine çağrıda bulunmuş ve başta klasik eserler olmak üzere destekleyici materyallerin okulların alım gücüne uygun makul fiyatlarla pazarlanması konusunda seçenek üretmelerini istemiştir. Bu çağrıya Penguin, Scholastics gibi kuruluşlar olumlu cevap vermiş; örneğin Scholastic, Black Classics serisinde bulunan 26 kitabın, tanesi 1,5 pounda gelecek şekilde çoklu baskılarını ${ }^{8}$ hazırlayacağını belirtmiştir (https://www.gov.uk/government/speeches/how-to-get-more-highquality-textbooks-into-classrooms).

Yukarıda ana hatlarıyla değinilen 7 Kasım 2015 tarihli konuşmasında Bakan, 1966 yılında University of East Anglia'dan bir grup araştırmacının bir gözlemini aktararak dinleyicilerden sözü edilen ülkeyi tahmin etmelerini istemiştir. Araştırmacıların tasviri, gözlemlenen duruma dair olumlu bir tutumu yansitmamaktadır. Ancak mesafeli bir tutumla anlatılan ülke, uluslararası sınavlarda uzun yıllar liderliğini koruyan Finlandiya'dır. Rapordaki ifadeler şöyledir: " "Bütün sınıf, öğretmen tarafından tayin edilen bir hızda, satır satır kitapta

\footnotetext{
6 "Given what we know about the success and failure of educational systems, we would be better off listening to teachers from South Korea and Taiwan than advisers from the USA."

${ }^{7}$ Matematik yuvası (Math hubs): Matematik eğitimiyle ilgilenen profesyonelleri 35 farklı merkezde bir araya getiren bir program. Her bir merkezin öncülüğü, bölgenin önde gelen okul ya da kolejlerince yapılmaktadır. Merkezlerin amacı matematik öğretimiyle ilgili birinci sınıf uygulamalar geliştirerek bunları ülke genelinde yaygınlaştırmaktır.

${ }^{8}$ Çoklu baskılar, belli bir sınıf düzeyindeki bütün öğrencilerin okuması beklenen kitaplar için yapılmaktadır. Bu kitapların baskı kalitesi orijinaline göre düşüktür. Örneğin orijinal baskı renkli ve ciltli ise, çoklu baskılar siyah-beyaz ve karton kapaklı olabilmektedir. Coklu baskılar toptan satıs yoluyla pazara sunulmaktadır.

9 "Whole classes following line by line what is written in the textbook, at a pace determined by the teacher. Rows and rows of children all doing the same thing in the same way whether it be art, mathematics or geography. We have moved from school to
} 
yazılanları takip ediyor. Sıra sıra öğrencilerin hepsi, ister sanat, isterse matematik ya da coğrafya olsun, aynı şeyi, aynı şekilde yapıyor. Okuldan okula dolaştık ve neredeyse aynı dersleri gördük. (Fakat) mesela, öğrenci merkezli öğrenme veya bağımsız öğrenmeye dair bir belirtiye pek rastlamadık." Gibb'in, bu örneği farklılaştırılmış/bireyselleştirilmiş/öğrenci merkezli öğretim konusunda İngiliz eğitimine yön veren görüşleri tartışmaya açmak gayesiyle verdiği açıktır. Ancak bu konuda İngiliz eğitim camiasında bir direnç olduğu gözlemlenmektedir. Zira bu konuşmadan 1 ay kadar önce, İngiltere'nin en büyük öğretmen sendikası olan NASUWT'un genel sekreteri "Bunun arkasında öğrenme konusunda çok daha katı ve dar planları zorla kabul ettirmeye yönelik bir gündem pusuya yatmış durumdadır. Hükümet, bütün çocukların biricik olduğu ve yeterlilik düzeyleri ile öğrenme ve bilgiyi özümseme kapasitelerinin farklı olduğunu kabul etmeksizin 'her bedene göre tek kıyafet' politikası güdüyor. Hükümet, 'Bakanlar en iyisini bilir.' yaklaşımından vazgeçmeli ve öğretmenlerin profesyonelliklerine saygılı olmalıdır." 10 şeklinde oldukça sert diye nitelendirebileceğimiz ifadelerle eğitimi tek tipleştirecek uygulamalara karşı olduklarını belirtmiştir (https://www.express.co.uk/news/uk/611221/UK-schools-back-books-bid-closegap-best-countries).

İngiltere'de ders kitapları ile ilgili tartışmalar konusunda sosyal medya ortamında dile getirilen görüşler de dikkat çekicidir. Bu platformlar öğretmen, öğrenci ve velilerin görüşlerini özgürce dile getirebilmelerine imkân sağlaması açısından önemlidir. Aşağıdaki tabloda ülkenin önde gelen eğitim sitelerinden www.tes.com'un forum bölümünde 2017 yılı Aralık ayında İngiliz okullarında neden ders kitabı kullanılmadığ 1 konusunda yapılan bir tartışmaya ilişkin görüşler yer almaktadır.

Tablo 1. "Birleşik Krallık okulları neden ders kitabı kullanmıyor?” tartışması

\begin{tabular}{|c|c|c|}
\hline GÖRÜŞLER & & Why do UK Schools not Use Textbooks? 2 Aralık 2007-9 Nisan 2019 \\
\hline $\begin{array}{l}\text { Ders Kitabı } \\
\text { Konusundaki } \\
\text { Görüşler }\end{array}$ & $\begin{array}{r}\text { Kullanımı } \\
\text { Olumlu }\end{array}$ & $\begin{array}{l}\text { 1. Ders kitapları maddi imkânları yetersiz veliler için iyidir. } \\
\text { 2. Ders kitapları ekip çalışmasının ürünüdür. Bu insanlar uzmandır ve bütün } \\
\text { işleri kitap yazmaktır. Bu nedenle bir öğretmenden daha iyi materyaller } \\
\text { üretebilirler. } \\
\text { 3. Ders kitapları incelemeden ve bazı durumlarda pilot uygulamadan geçtiği } \\
\text { için daha güvenilir kaynaklarıdır. } \\
\text { 4. Bazı ders kitapları internet aracılığıyla destekleyici kaynaklar, zengin } \\
\text { materyaller sunabiliyor. } \\
\text { 5. Öğretmen kitabı, ders kitabı, farklı düzeydeki öğrenciler için farklı çalışma } \\
\text { ve değerlendirme kitapları gibi kitaplardan oluşan kapsamlı setler faydalıdır. } \\
\text { 6. Öğrenciler ders kitabının tasarımını seviyorlar. } \\
\text { 7. Ders kitapları öğrencilerin "nereden başladık, neredeyiz, nereye gidiyoruz" } \\
\text { şeklinde bir fikre sahip olmasını kolaylaştırır. } \\
\text { 8. Sağlam, bütünlük taşıyan bir eğitim için kitap faydalıdır. Öğrenci bütün bir } \\
\text { içeriği elinde tuttuğu için geri dönüp bakabilir, ileri gidip büyük resim } \\
\text { içinde kendi öğrenmesinin yerini görebilir. } \\
\text { 9. Dersi kaçıran öğrencilerin evde çalışmaları için ders kitapları rehber } \\
\text { niteliğindedir. } \\
\text { 10. Eski kitapları ihtiyaç olursa diye muhafaza ediyoruz. Müfredat ne kadar } \\
\text { değişirse değişsin çoğu şey kitaplarda var olmaya devam ediyor. }\end{array}$ \\
\hline $\begin{array}{l}\text { Çalışma Kâğıdı } \\
\text { Konusundaki } \\
\text { Görüsşler }\end{array}$ & $\begin{array}{r}\text { Kullanımı } \\
\text { Olumsuz }\end{array}$ & $\begin{array}{l}\text { 1. İnternette kaynak çok olmakla birlikte uygun çalışma kâğıdını bulmak } \\
\text { oldukça uzun ve yorucu bir süreçtir. } \\
\text { 2. Çalışma kâğıtlarıyla ilgili planlama ve kaynak oluşturma çok zaman alıyor. } \\
\text { 3. Çalışma kâğıtlarını öğrenciye dağıtmak ve toplamak zordur. } \\
\text { 4. Çalışma kâğıtlarını deftere yapıştırmak ayrıca bir zaman gerektiriyor. } \\
\text { 5. Çok az çalışma kâğıdı kitaptan daha iyi olup çoğunlukla da kitabın }\end{array}$ \\
\hline
\end{tabular}

school and seen almost identical lessons... [We] did not see much evidence of, for example, student-centred learning or independent learning".

10 "Lurking behind this is an agenda to impose even more rigid and narrow plans for learning. The Government is moving down the road of a one-sizefits-all policy without recognising that children are unique and have different levels of ability and different capacities to learn and absorb information. The Government needs to abandon its 'ministers know best approach' and to respect teachers' professionalism." 


\begin{tabular}{|c|c|}
\hline & $\begin{array}{l}\text { içeriğiyle örtüşmektedir. } \\
\text { 6. Bazı çalışma kâğıtları ders kitaplarından hareketle üretilmektedir. Bu } \\
\text { tekerleğin yeniden keşfi gibi bir şeydir. } \\
\text { 7. Çalışma kâğıtları öğrencilerin okuma yazma becerilerini köreltmektedir. Bir } \\
\text { kitapta sayfa numaralarını ne işe yaradığını bilmeyen öğrenciler } \\
\text { olabilmektedir. } \\
\text { 8. Çalışma kâğıtları öğretmenlerin kendilerini iş yapıyor göstererek idarenin } \\
\text { takdirini toplama çabasıdır. Çünkü ders kitabı kullanma, tembel öğretmen } \\
\text { algısına yol açmaktadır. } \\
\text { 9. Çalışma kâğıdı kullanımı masraflı bir iştir. Çünkü fotokopi ücreti kitap } \\
\text { ücretini aşmaktadır. }\end{array}$ \\
\hline Diğer Görüş ve Yorumlar & $\begin{array}{l}\text { 1. Ders kitapları bilgi içerir. Bilgi eğitim sistemimizde tehlikeli bir şey olarak } \\
\text { görülmektedir. Konuya ilişkin bilgiden ziyade düşünme becerileri } \\
\text { öncelenmekte; olguları bilmek değil, beceri kazanmak önemli vurgusu } \\
\text { yapılmaktadır. Oysa ikisi de önemli olmalı ve ölçme değerlendirme de bunu } \\
\text { dikkate almalıdır. } \\
\text { 2. Kanun gereği okul veliyi kitap almaya zorlayamadı̆̆ı için ders kitabı } \\
\text { kullanılmamaktadır. } \\
\text { 3. Öğretim programının yapısı ders kitabı kullanımını zorlaştırmaktadır. } \\
\text { Program çok sık değişiyorsa ders kitaplarının buna ayak uydurması zordur. } \\
\text { Ayrıca ders kitapları için elverişli materyallerdir. } \\
\text { 4. Ders kitabı kullanmamanın mantıklı bir açılaması yoktur. Bir zamanlar } \\
\text { ders kitabı modaydı, şimdi değil, zamanı gelince yine moda olacaktır. } \\
\text { 5. Kitabı satır satır takip edip gerçek anlamda öğrenmeyi ihmal eden } \\
\text { öğretmenler vardı. Çalışma kâğıdı hazırlama zorunluluğu öğretmeni daha } \\
\text { çok çalıştıracağı için ders kitabı kullanılmıor. } \\
\text { 6. Ders kitaplarının içeriği yetersiz olduğu için kullanılmasından vazgeçildi. } \\
\text { 7. Politikacılar değişince kitapların da yeni politikalar doğrultusunda } \\
\text { değişmesi gerekir. Bu da zaman alıcıdır. Çünkü kısa sürede yeni politik } \\
\text { söylemin kitapları yazılamaz. Bu boşluk çalışma kâğıtlarıyla } \\
\text { doldurulmaktadır. }\end{array}$ \\
\hline
\end{tabular}

Kaynak: https://community.tes.com/threads/why-do-uk-schools-not-use-textbooks.768076/

$\mathrm{Bu}$ tartışmaya dunnocks kullanıcı adlı bir öğretmenin verdiği cevap ise içerdiği duygusal ton bakımından dikkat çekicidir. Bu kullanıcı ders kitaplarını dışlayan tutumu, karar vericilerin öğrenciyi şımartan ve öğretmenleri âdeta onların kölesi hâline getiren çalışma kâğıdı kullanımına karşı çıkarken, konuyla ilgili bilimsel araştırmalara güvensizliğini dile getirmekte ve fotokopi endüstrisinin de bu işten bir çıkarı olduğuna dair şüphelerini ironik bir şekilde ifade ederek orta öğretimde bile henüz bir kitaptaki sayfa numaralarının ne işe yaradığını bilmeyen öğrenciler bulunduğundan şikâyet etmektedir. Bu cümlelerle dile getirilen görüş, içerikten çok öğretmenlerin tepkilerini göstermesi bakımından dikkat çekici olup anti-ders kitabı söylemlerinin hâkim olduğu bir ortamda direnci kırmanın zorlukları hakkında da fikir vermektedir.

Daha önce de ifade ettiğimiz üzere özellikle Eğitim Bakanı Gibb'in gayretleriyle başlayan anti-ders kitabı tutumunu yumuşatmaya yönelik çalışmalar, İngiltere'de çok yavaş ilerlemektedir. Ders kitapları konusunda kayda değer mesafe ancak matematik ders kitapları için kat edilebilmiş durumdadır. Hükümet, 2017 y1lında 36 kitaptan oluşan Real Shangai Mathematics serisini çevirerek piyasaya sürme kararı almış, bu iş için de 54 milyon dolarlık bir kaynak planlaması yapmıştır (The New York Times: 5 Ağustos 2017; https://www.studyinternational.com/news/uk-china-text-books-improve-test-score/). $\mathrm{Bu}$ ders kitaplarıyla aynı zamanda Birleşik Krallık genelindeki matematik eğitim sistemini de değiştirmek amaçlanmaktadır. Zira adı geçen ders kitapları az sayıdaki matematik kavramını derinlemesine öğretme ve bütün sınıfın aynı konu üzerinde çalışmasını sağlama esasına dayalıdır. Sınıftaki bütün öğrencilere aynı konunun öğretilecek olması baştan beri dikkat çekmeye çalıştığımız farklılaştırılmış/bireyselleştirilmiş öğrenme felsefesinin esas olduğu bir sistemde önemli bir paradigma değişikliğine işaret etmektedir. $\mathrm{Bu}$ yüzden Bakanlık, öğretmenleri ders kitaplarını kullanma veya kendi müfredatlarına adapte/entegre ederek kullanma konusunda serbest bırakmıştır. 
Eğitim sistemindeki paradigma değişikliğiyle ilgili bir diğer işaret de ders kitaplarıyla "bilgiden zengin" bir öğretimin hedefleniyor olmasıdır. Yukarıdaki tabloda İngiliz eğitim sisteminin düşünme ve beceri temelli olduğu ifade edilmişti. Bugün itibarıyla bu esaslardan vazgeçilmemekle birlikte bunların bilgi ile desteklenmesi gerektiği yüksek sesle dile getirilmektedir. Gibb'in 1 Aralık 2017 tarihli konuşmasında sık sı "knowledge-rich (bilgiden zengin)" ifadesini tekrarlaması, İngiliz eğitim sisteminde yakın gelecekte ders kitapları aracıllğıyla gerçekleştirilecek bir değişimi haber verir niteliktedir.

\section{Sonuç ve Öneriler}

1. Görüldüğü gibi Birleşik Krallık’taki devlet okullarında ders kitabı kullanımı 1970’ten sonra büyük ölçüde azalmıştır. Son yıllarda bu eğilimi tersine çevirme yolunda özellikle Eğitim Bakanlığı destekli çalışmalar görünür hâle gelmiştir. Ancak kısa vadede ders kitabı kullanımının yaygınlaştırılması pek mümkün görünmemektedir. Bugün itibarıyla ders kitabı kullanımı konusunda en somut adım ancak matematik dersi için atılabilmiştir. Söz gelimi dil ve edebiyat dersleri için ders kitabı kullanımından söz edilmemektedir.

2. Ders kitabı kullanılmamasını arka planındaki iki temel dinamik farklılaştırılmış/bireyselleştirilmiş öğrenme ve öğrenmeyi öğretme şeklinde bildiğimiz bilgiyi ikinci planda gören anlayıştır.

3. Birleşik Krallık’ta ders kitabı kullanımının zamanla azalmış olması biraz da ülkenin kozmopolit yapısının bir sonucu olarak değerlendirilebilir. Dünyanın her yerinden gelen çocukların yaşıtlarıyla aynı sınıfta okuma zorunluluğu, aynı sınıf içerisinde hem dil hem de kültür açısından bazı seviyeler ortaya koymaktadır. Aynı sınıfta üç dört farklı seviyede öğrencinin bulunması aynı kitabın kullanılmasını zorlaştıran bir husustur. Bu sebeple seviyesine göre gruplara ayrılmış öğrencilere konunun niteliğine uygun ders materyali hazırlayıp dağıtmak sistem açısından daha mantıklı görünmektedir. Bu anlayış yaygınlaştığı için yayınevleri ders kitabı basmak konusunda artık hevesli değillerdir. Devletin kitap kullanımını yaygınlaştırmak konusunda gayreti söz konusu olsa da ücretsiz kitap dağıtmak gibi bir düşüncesi kısa vadede mümkün görünmemektedir.

4. Ders kitaplarının kullanılmaması öğretmenlerin kendi materyallerini hazırlama zorunluluğunu beraberinde getirmekte, bunun bir sonucu olarak da eğitim içerikli siteler ders kitaplarının yerini almaya devam etmektedir.

5. Ulusal ölçekli sınavlarda her zaman üst sıralarda yer alan Uzak Doğu Ülkeleri, Finlandiya ve Singapur gibi ülkelerde kitap kullanımı sistemin vazgeçilmez bir unsuru olmaya devam ederken yine siralamada ülkemizin üstünde yer alan İngiltere gibi ülkelerde de kitap kullanılmadığ1 görülmektedir. Özellikle fen bilimleri ve matematik gibi uluslararası geçerliği olan derslerde başarılı olan ülkelerin kitaplarını incelemek, derslerde kullanılan yöntem ve teknikleri tespit etmek iyi örneklerin değerlendirilmesi açısından önem arz etmektedir. Ancak burada her ikisi de uluslararası sınavlarda ülkemizin önünde olan iki farklı coğrafyadan iki farklı pratik söz konusudur. Bu noktada, "Biz hangi uygulamadan yana tavır koyacağı??" sorusu, ülkemizin sosyo-kültürel bağlamı, eğitime ayrılan kaynakların kullanımı ve eğitim uygulamalarına yön veren felsefe tarafından tayin edilecektir.

6. Ders kitaplarının niteliği ile ilgili önemli sorunlarımız olduğu bir gerçektir. İçeriğge gelmeden önce sadece baskı ve resim kalitesi konularında bile ders kitaplarında eleştirilecek çok şey bulunabilir. Bu bağlamda çalışmamız herhangi bir öneri getirme amacı taşımamakta; farklı ülkelerdeki uygulamaları ve bunları yöneten felsefeyi açarak eğitim camiasında yapılmakta olan ve ileride yapılacak olan tartışmalara "Bu hususları da dikkate alalım." gibi mütevazı bir katkı sunmak istemektedir. Nitelikli bir öğretim, nitelikli öğretim materyalleriyle yapılabilir. Nitelikli eğitim materyali geliştirmek ve bunları uygulayacak öğretmeni yetiştirmek elbette sistemin devamı açısından çok önemlidir. Daha da önemlisi ise eğitimle ilgili alınacak kararların, yapılacak çalışmaların kendi bağlarımızla, eğitime bakış açımızla, eğitim felsefemizin bel 
kemiğini oluşturan düşüncelerle, eğitime ayırabildiğimiz kaynaklarla, öğrenci, öğretmen, veli beklentileriyle uyumlu olmasıdır.

\section{Kaynakça}

Alkan, T. (1979). Siyasal toplumsallaşma. Ankara: Kültür Bakanlığı Yayınları.

Altan, C. (2011). Eğitim-siyasal eğilim ilişkisi: Mersin örneği. Cumhuriyet Üniversitesi İktisadi ve İdari Bilimler Enstitüsü Dergisi, 12(1), 313-329.

Altun, M. Arslan, Ç. Yazgan, Y. (2004). Lise Matematik Ders Kitaplarının Kullanım Şekli ve Sıklığı Üzerine Bir Çalışma. Eğitim Fakültesi Dergisi XVII (2), 2004, 131-147.

Araujo, L. Slatelli, A, Schnepf, S. (2017). Do PISA Data Justify PISA-Based Education Policy International Journal of Comporative Education and Development, C.19, S.1, s.1-17.

Aslan, E. (2010) Dokuz Eylül Üniversitesi, Buca Eğitim Fakültesi, Eğitim ve Bilim Cilt 35, Sayı 158.

Bakioğlu, A. (2018). Karşılaştırmalı Eğitim Yönetimi, Ankara: Nobel yayınları.

Coşkun, D. Y. (2017). Öğretim Programları Arka Planı Raporu, Eğitim Reformu Girişimi, İstanbul.

Çakır, P. (2013). Türkçe Ders Kitaplarındaki Öykülerin Çocuğa Görelik İlkesi Açısından İncelenmesi. Ankara: Turkish Studies - International Periodical For The Languages, Literature and History of Turkish or Turkic Volume 8/1, p.1171-1180.

Çalışkan, N. (2006). Türkiye'deki Ortaöğretim Edebiyat Ders Kitapları Üzerine Edebiyat Eğitimi Açısından Bir Değerlendirme, Millî Eğitim, 34 (169), s. 355-365.

Çınkır, Ş. (2010). Eğitim örgütlerinde Yeniden Yapılanma ve Kapasite Geliştirme: $A B$ Ülkelerinde Örnekler. Ankara: Ekinoks Yayınları.

Demirkaya, H. Tomal, N. (2002). Lise coğrafya Ders Kitaplarının Değerlendirilmesi ve Sorunlara Yönelik Çözüm Önerileri. Ankara: Coğrafya Kurultay1, 9-11 Temmuz, s.12-134.

Fernandez-Cano, Antonio (2016). A Methodological Critique of the PISA Evaluations. RELIEVE, 22(1), art. M15. DOI: http://dx.doi.org/10.7203/relieve.22.1.8806

Goldstein, H. (2017). Measurement and evaluation issues with PISA. In The PISA effect on global educational governance, ed. Louis Volante, New York and London, Routledge.

Göçer, A. (2007). Illköğretim Türkçe Ders Kitaplarının Ölçme ve Değerlendirme Açısından İncelenmesi. Çukurova Üniversitesi III. Sosyal Bilimler Eğitimi Kongresi. 197-210.

Gülersoy, A. (2013). İdeal Ders Kitabı Arayışında Sosyal Bilgiler Ders Kitaplarının Bazı Özellikler Açısından İncelenmesi. International Journal of New Trends in Arts, Sports \& Science Education ,2, issue 1.

Gürses, F. ve Pazarcı, N.G. (2010). Siyasal gündemin yurttaşlık kavramına etkileri: Ders kitaplarl üzerinden bir inceleme. İzmir. 5. Karaburun Bilim Kongresi.

Işıksalan, N. (2004). Türk Edebiyatı Ders Kitaplarının İçerik Değerlendirilmesi - II (19502000). Eğitim ve Bilim, 29, (132), 48-57.

Kaplan, İ. (1999). Türkiye’de Millî Eğitim İdeolojisi. İstanbul: İletişim Yayınları.

Millî Eğitim Bakanlığı Ders Kitapları ve Eğitim Araçları Yönetmeliği-2016

http://pisa.meb.gov.tr/wp-content/uploads/2014/11/PISA2015_UlusalRapor.pdf.

http://www.resmigazete.gov.tr/eskiler/2012/09/20120912-2.htm

https://community.tes.com/threads/why-do-uk-schools-not-use-textbooks.768076/. 
https://www.cambridgeassessment.org.uk/insights/why-do-students-still-need-textbooks/.

https://www.express.co.uk/news/uk/611221/UK-schools-back-books-bid-close-gap-best countries.

https://www.gov.uk/government/speeches/how-to-get-more-high-quality-textbooks-intoclassrooms.

https://www.meb.gov.tr/bakan-selcuk-tbmm-plan-ve-butce-komisyonunda-sunumyapti/haber/17391/tr.

https://www.nytimes.com/2017/08/05/world/asia/china-textbooks-britain.html 05.08.2017.

https://www.studyinternational.com/news/uk-china-text-books-improve-test-score/.

https://www.telegraph.co.uk/education/educationnews/11241014/Schools-told-reintroduce traditional-textbooks-in-lessons.html 20.11.2014.

https://www.telegraph.co.uk/education/educationopinion/11739310/Textbooks-have-a-hugeimpact-on-education.html 15.07.2015.

National Curriculum, (2014). https://www.gov.uk/government/collections/national-curriculum.

Oates, T. (2014). Ders Kitapları Neden Önemlidir? (Why Textbooks Count?). University of Cambridge Assesment, s. 1-23.

Özgen, B. (1993). Türkiye'de Ders Kitapları Sorunu ve Çözüm Yolları. Eğitim ve Bilim. 17 (87), s.48-59.

Pingel, F. (2003). Ders Kitaplarını Araştırma ve Düzeltme Rehberi (UNESCO), İstanbul: Tarih Vakfi Yurt Yayınları.

Svein Sjøberg (2015) Eurasia Journal of Mathematics, Science \& Technology Education, 11(1), 111-127, International Society of Educational Research ISSN: 1305-8223 PISA and Global Educational Governance - A Critique of the Project, its Uses and Implications. University of Oslo, NORWAY.

Svein Sjøberg (2018). The power and paradoces of PISA: Should Inquiry-Based Science Education be sacrificed to climb on the rankings?- University of Oslo, NORWAY.

Uyan, S. (2015). Türkiye ve Finlandiya Eğitim Sistemleri Arasındaki 15 Fark.

http://www.gelecekegitimde.com/turkiye-ve-finlandiya-egitim-sistemleri-arasindaki-15-fark/ adresinden 31.03.2019 tarihinde erişildi.

Ülper, H. ve Yalınkılıç, K. (2010). Son Türkçe Programına Göre Hazırlanan Türkçe Ders Kitaplarındaki Metin Sonu Sorularının Nicel ve Nitel Görünümü. Uluslararası Sosyal Araşttrmalar Dergisi, 3 (12), s. 449-461.

Yıldırım, A. ve Şimşek, H. (2016). Sosyal Bilimlerde Nitel Araştırma Yöntemleri. 10. Baskı. Ankara: Seçkin Yayınları.

\section{ETİK ve BİLIMSEL İLKELER SORUMLULUK BEYANI}

Bu çalışmanın tüm hazırlanma süreçlerinde etik kurallara ve bilimsel atıf gösterme ilkelerine riayet edildiğini yazar(lar) beyan eder. Aksi bir durumun tespiti halinde Afyon Kocatepe Üniversitesi Sosyal Bilimler Dergisi'nin hiçbir sorumluluğu olmayıp, tüm sorumluluk makale yazarlarına aittir. 